\title{
Mapping of Planning Land Use Based GIS in Sub-District Kintamani, Bali
}

\author{
Made Sri Sumarniasih \\ Department of Agroecotechnology, Faculty of Agriculture, Udayana University, Denpasar, Bali-Indonesian
}

\begin{abstract}
Research land use plans implemented in Kintamani Sub-district, Bangli Regency, Provence of Bali. The Soil samples were collected by overlaying maps of soil types, land use maps, maps of slope, so we get a map of the land unit with 48 sample points. . The scoring method used to analyze slope, soil type and rainfall. The results of the analysis are used to plan the direction of land use in the Kintamani district. Land use is as a buffer zone and protected areas, land outside the forest area. The existing condition of the land is owned by farmers, the use of land in the buffer zone, with intercropping and organic matter or mulching, while in protected areas which are land use under the conditions then existing rules soil and water conservation.
\end{abstract}

Keyword-mapping, land use planning, GIS.

\section{INTRODUCTION}

The use of land in the sub-district of Kintamani is still less attention to the rules of conservation, in areas with a slope of over $25 \%$, is still used for farming seasonal crops. As is known sub-district of Kintamani is upstream of several rivers vital for the region Bali, one of which is the Watershed (DAS) Ayung [4]. Overcome this, is necessary improvement efforts follow the rules of soil and water conservation to reduce damage to the land and can provide benefits for farmers, and increased revenue. The results of this study are expected to provide a positive impact on soil and water conservation, conservation area planted area, the increase in the production of agricultural commodities and sustainably to improve the welfare of farmers [1].

Geographic Information Systems (GIS) is an information management tool that is strongly associated with mapping and analysis of all things and events that occur on earth. GIS is a computer-based system used to store, manipulate, and analyze geographic information, original information earth's surface is presented in the form of a map created manually, then with the presence of GIS, information is processed by a computer, and the results in the form of digital maps [3]. SIG not only function "map maker", but further than that, SIG is able to produce an information system that is applied, which can be used by planners or decision maker for the purposes of processing resources that exist in the region. Developments will update spatial data in the era of science and technology advancement is increasingly needed, but requires accurate data, practical, and efficient. Their GIS applications can act as a substitute for maps wall, which was replaced with the display layers of digital maps (spatial database) with symbols and colors that appeal. Development application SIG is no longer something that is considered expensive, because it has a lot of GIS software which is free and open source, such as Map Window, Quantum GIS, and others [5], [6].

Based on the problems outlined above, it is necessary to study the direction of land use plans based on the assessment of scores of slope, soil type and rainfall. The results of the analysis with the scoring method was presented in the form of digital maps using GIS application.

\section{RESEARCH METHODS}

\subsection{Research Sites}

The study was conducted on multiple land use in the district of Kintamani, Bangli, Bali Province. Geographically located at $115^{\circ} 18^{\prime} 27^{\prime \prime}$ BT until $115^{\circ} 23^{\prime} 00^{\prime \prime B T}$ and $08^{\circ} 10^{\prime} 00^{\prime \prime L S}$ until $08^{\circ} 20^{\prime} 00^{\prime \prime L S}$. Tools that be used in this study were: 1) map appearance of the earth (1: 25,000), a map of soil types (1: 25.000), land use maps (1: 25,000) [2], (2) GPS, (3) plastic bags, paper labels, Abney level, meter, ring samples, knives, pens, and drill ground; (4) Photo camera for creation of documentation; and (5) A set of PC computer for data processing

\subsection{Research Procedure}

Research procedures are as follows:

1) Digitizing a map of the study area.

2) Making a map overlay of the land unit based of map soil type, slope maps and land use maps, in order to obtain a map of the land unit "Fig 1". [8].

3) Based on the map of the land unit gained 48 points soil samples to be analyzed in the Laboratory of Soil and Environment Faculty of Agriculture, University of Udayana. 
4) Analyze slope, soil type and daily rainfall with the scoring method.

\subsection{Analysis Method}

Determining the direction of the use of land use by methods proposed by Sukartiko [7]. The system is based on three criteria: the field slope, soil type according to sensitivity to erosion and precipitation daily average. Each of these factors in value/ the weight in accordance with the level of influence relative to the sensitivity of the area concerned on erosion.

Classification for each factor is as follows:

1. Slope Field
A. $=0$ to $3 \%$ (flat)
B. $=3$ to $8 \%$ (ramps or wavy)
C. $=8$ to $15 \%$ (slightly sloping or bumpy)
D. $=15$ to $30 \%$ (sloping or hilly)
E. $=30$ to $45 \%$ (rather steep)
F. $=45$ to $65 \%$ (steep)
G. $=$ more than $65 \%$ (very steep)

2. Soil type according to their susceptibility to erosion

Class 1 = Alluvial Land Glei, Planosol,

Hidrimorf gray, Laterik ground water. (not case sensitive)

Class 2 = Latosol (somewhat sensitive)

Class 3 = Brown Forest Soil, Non Calsic Brown, the

Mediterranean (less sensitive)

Class 4 = Andosol, laterite, Grumusol, Podsol,

Podsolic (sensitive)

Class 5 = Regosol, Litosol, Organosol, Renzina

(very sensitive).

3. The intensity of the rainfall average

Class $1=0$ to $13.6 \mathrm{~mm} /$ day (very low)

Class $2=13.6$ to $20.7 \mathrm{~mm} /$ day (low)

Class $3=20.7$ to $27.7 \mathrm{~mm} /$ day (medium)

Class $4=27.7$ to $34.8 \mathrm{~mm} /$ day (high)

Class $5=>34.8 \mathrm{~mm} /$ day (very high).

The weights of each class is 20 to slope factor field, 15 to soil types and 10 for an average rainfall intensity, thus for each class factors are as follows:

1. Slope field

Class $1=20$

Class $2=40$

Class $3=60$

Class $4=80$

Class $5=100$

2. The type of soil according to sensitivity to erosion

Class $1=15$

Class $2=30$

Class $3=45$

Class $4=60$

Class $5=75$
3. The intensity of the average daily rainfall

Class $1=10$

Class $2=20$

Class $3=30$

Class $4=40$

Class $5=50$

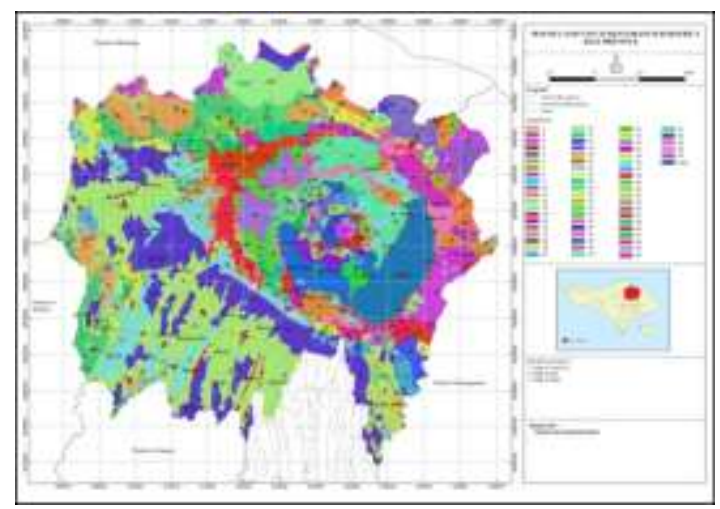

Fig 1. Unit Maps of Land and Soil Samples

Furthermore, the determination of the direction of land use for each unit of land is done by showing the values score above three factors by observing the status of the land area. Differentiated land area of land within the forest and land outside the forest area. In accordance with its designation, land within the forest can be classified into: protected forests, production forests, forest preserves and forests. Land outside the forest area is classified as a protected area, buffer area, cultivated area of crops and seasonal crops cultivation areas.

\section{A). In the Forest Area}

1. Forest Preserve

Based on the sum of the value of the score, then an area declared to be a forest area, fostered and maintained as protected forests if the total value of the score is equal to or greater than 175 .

2. Production Forest

Production forests are classified into: a limited production forest logging with a total score of 125174 and production forests free total score equal to or less than 124 , outside the forest area of nature reserves, forests and other conservation tour.

3. Forest nature reserve and Tourism

Determination of nature reserves and tourist assessment is not based on these factors, but more focused on the interests of culture, germ plasm conservation and recreation.

B). Beyond the Forest Area

1. Protected Areas

Establishment of protected areas in the same way that the establishment of protected forests if the 
amount of the value of a score equal to or greater than 175 .

2. Buffer Zone

An area is declared as a buffer zone when a score is $125-174$ and or meet some general criteria as follows:

- The physical state it is possible to do farming region economically.

- Economically convenient location developed as a buffer zone.

- No adverse aspects of ecology/ environment.

3. Region Annual Crop Cultivation

An area designated as an area of cultivation of annual crops if the region have a total score of equal to or less than 124 and is suitable or annual crop farming should be developed (timber, plantation crops, and industrial plants).

4. Plant of Annuals

Areas with criteria such as the determination of annual crop cultivation area, but the area is located on land owned, indigenous lands and state lands that should be developed farming seasonal crops.

\section{Table 1. Land Use Planning in Sub-District Kintamani}

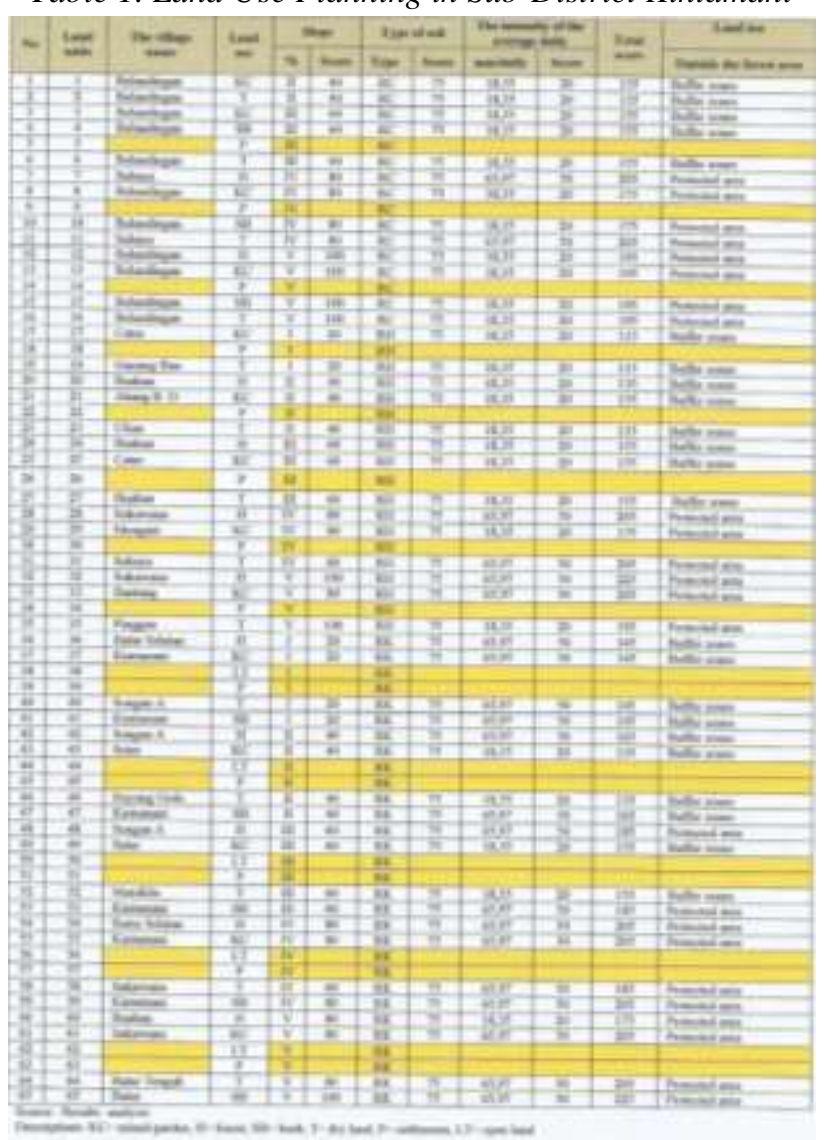

\section{RESULTS AND DISCUSSION}

Research was conducted on different land use in the district of Kintamani Bali. This region is upstream of the watershed (DAS) Ayung, one of the longest river basin in the province of Bali, then in determining the direction of land use must pay attention to the rules of soil and water conservation. Under these conditions, the factors that influence erosion are also factors that need attention, and can be broken down as follows:

1) Climate is a factor that affects hydrological processes and is an important element in the process of hydrology. Elements of the climate that affect most of the hydrological processes that are rainfall. Data rainfall in the district of Kintamani obtained from Tuban Meteorology and Geophysics Agency (BMKG). At the observation post in the village of Kintamani, the amount of rainfall average was 68.97 $\mathrm{mm} /$ day and for the observation post Catur $38.73 \mathrm{~mm}$ /day.

2) The type of soil in the district of Kintamani (BPDAS, 2009), is a type of Regosol Humus soil, Regosol Regosol Brown and Gray each covering an area of 8729,74 ha; 12014.61 ha and 412.90 ha. This type of soil is sensitive to erosion, if the land use does not follow the rules of soil and water conservation. If it rains with high intensity because of the type of soil susceptible to erosion, the surface soil layer (top soil) is easy to carry rainwater runoff into the form of erosion or landslides.

3) Factors topography of research showing the shape of the area, including differences in slope steepness or slope. Increasingly steep slope, the greater the rainfall becomes runoff or erosion caused by rainwater was not given the opportunity infiltrated. Slope area of research is the slope of class I to class $\mathrm{V}$.

4) The land use is upland area of, 55 ha; 994.73 ha mixed farms; 318.51 ha of forest; bush 175.64 ha; open land and undeveloped land 163.46 ha and 78.34 ha.

The results of the analysis with the scoring method using the data of slope, soil type and rainfall daily average, then the use of land in the district of Kintamani directed to the protected area and the buffer zone is presented in Table 1. Referral land use for 48 sample points vary according to the value of scores obtained from summing the values score above three factors with pay attention ownership status of the land.

Status distinguished tenure on the land in the forest area and land outside the forest area. Land in the forest area can be classified into: protected forests, production forests, forest preserves, and forests. Land outside the forest area is classified into: protected areas, buffer zones, annual crop cultivation area and cultivation area of seasonal crops.

(A) Land in the area is divided into:

1. Forest Preserve: 175-value or more 
2. Production Forest: value 125-174

3. Forest Nature Reserve and forest tour

(B) Land outside the forest area

1. Protected Areas: equal to 175 or greater.

2. Buffer Zone: value 125-174

3. The annual crop cultivation area: the value is less than 124

4. Region cultivation of seasonal crops: lands, indigenous lands and state lands

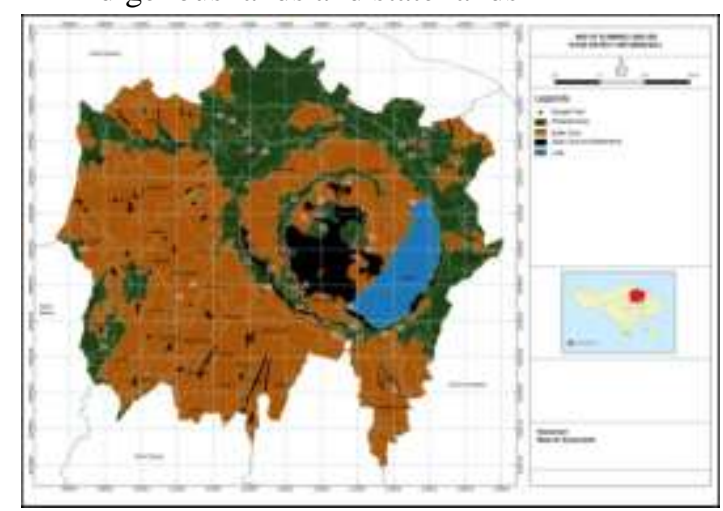

Fig.2: Land Use Planning in Sub-Distrct Kintamani

The total scores obtained from the analysis are:

135-225, because the land is outside the forest area and owned by farmers, then the direction of land use are:

1. Protected areas

2. Buffering Region

Land unit: 1, 2, 3, 4, 6, 17,18, 20, 21, 23, 24, 25, 27, 36, $37,40,41,42,43,46,47,49$, and 52 . Have a total score of above 125 is (135 to 175). That is all geared land use as a buffer zone. The research location is outside the forest area and land belonging to the community or farmer, the land use to prevent land degradation due to erosion, is the use of conservation land. Communities in land use pattern suggested by intercropping and addition of organic materials or mulching. In addition to preventing erosion also maintain the fertility and quality of the land, so that high productivity can be achieved land unit that scored above 175 ie $(175-225)$ is a unit of land: $7,8,10,11,12,13,15,16,28,29,31,32,33,35,48,52$, $53,54,58,59,60,62,64$ and 65 as a protected area, but because of the study sites land ownership dominated owned by the community, then the direction of land use adapted to the land use existing. If previous already used for mixed farms it should be recommended to the conservation cropping pattern: the pattern of intercropping with organic matter or mulch. Whereas if the conditions existing is bush or forest, then referral to a protected area of forest remains, while in the bush land used for mixed garden high density, or planting timber trees by observing the rules of soil and water conservation. planning of land use is presented in "Fig 2 ".

\section{CONCLUSION}

Based on the results of the analysis can be concluded:

1) Land use in Kintamani are buffer zones and protected areas

2) In the buffer zone should be done planting intercropping (seasonal plant with annual crops or perennial plants with annual crops) and added organic matter or mulching.

3) In the protected area because the farmer's land as the existing condition of land use, cropping patterns which can be directed attention to the rules of land conservation.

\section{ACKNOWLEDGEMENTS}

Thanks to Ministry of Research and Technology who gave Grant Leading Universities so that this research can be done, and the Institute for Research and Community Service (LPPM) for all facilities provided.

\section{REFERENCES}

[1] Arsyad, S. 2000. Soil and Water Conservation. Press Publisher IPB, Bogor.

[2] Bakosurtanal. 2000. Map Rupa Bumi Indonesia. Jakarta.

[3] Barus B., and U.S. Wiradisastra, 2000, Geographic Information Systems, Laboratory of Remote Sensing and Cartography, Soil Department, Faculty of Agriculture, IPB, Bogor.

[4] BPDAS. Unda Anyar. 2009. Integrated Watershed Management Plan Watershed SWP Pangi Ayung. Report Watershed Management Center Anyar Unda. Denpasar.

[5] Darmawan Setiadi, I Made Nyoman Piarsa, Ni Made Ika Mandenni Marini. 2015. Mapping Geographic Information System Web-Based Population Growth Rate. In PIGEON Journal VOL. 3, NO. December 3, 2015. ISSN: 2252-3006. P. 180-189.

[6] Ramadona, A.L and Kusnanto.2010 Day. Quantum GIS Applications for Environmental Information System. Publisher BPFE Yogyakarta.

[7] Sukartiko, B. 1988. Land Capability Assessment System for Determination Tutorial Land Use Planning in the Framework of Watershed Management. Technical Meeting Standardization System of Classification and Land Survey Methods, Cibinong, Bogor

[8] Sumarniasih, Made Sri and Made Antara. 2016. Conservation planning on eroded land based of local wisdom in Kintamani sub-district. 